Maurice A. Deane School of Law at Hofstra University Scholarly Commons at Hofstra Law

Hofstra Law Faculty Scholarship

1978

\title{
Complementarity versus Similarity of Traits Operating in the Choice of Marriage and Dating Partners
}

Amnon Till

Eric M. Freedman

Hofstra Law School

Follow this and additional works at: https://scholarlycommons.law.hofstra.edu/faculty_scholarship

\section{Recommended Citation}

Amnon Till and Eric M. Freedman, Complementarity versus Similarity of Traits Operating in the Choice of Marriage and Dating Partners, 105 J. Social. Psyc. 147 (1978)

Available at: https://scholarlycommons.law.hofstra.edu/faculty_scholarship/521

This Article is brought to you for free and open access by Scholarly Commons at Hofstra Law. It has been accepted for inclusion in Hofstra Law Faculty Scholarship by an authorized administrator of Scholarly Commons at Hofstra Law. For more information, please contact lawcls@hofstra.edu. 


\section{COMPLEMENTARITY VERSUS SIMILARITY OF TRAITS OPERATING IN THE CHOICE OF MARRIAGE AND DATING PARTNERS*1}

Victoria University of Wellington, New Zealand

\section{Amnon Till and Eric M. Freedman}

In order to test the theory proposed by Winch, ${ }^{2}$ that people tend to choose partners whose need patterns are complementary, rather than similar, to their own, a cross-cultural study was conducted on students in the United States, Australia, and New Zealand. The obtained data tended strongly towards supporting the idea of similarity, rather than complementarity.

Our complete sample comprised three subsamples: (a) American-47 male and 67 female undergraduate students at Indiana University in 1974, between 18 and 22 years of age; (b) Australian-150 male and 150 female Melbourne high school students, between 16 and 18 years of age in 1975; and $(c)$ New Zealand-31 male and 46 female undergraduate students at Victoria University of Wellington in 1976, between 18 and 22 years of age. All students were single and natives of their respective countries.

The $S$ s completed their three Osgood Semantic Differential Scales, dealing with their self-perceptions, perceptions of their preferred dating partners, and perceptions of their preferred marriage partners. The complete scale consisted of 27 bipolar items dealing with psychological characteristics (e.g., tense-relaxed), social characteristics (e.g., rich-poor), and physical characteristics (e.g., tall-short). Each bipolar pair was separated by seven scalar divisions, and the $S$ responded by marking the scale at the point which seemed most appropriate to him.

The $S \mathrm{~s}$ in the American sample completed only the first 18 of the 27 items. The Australian students completed only two Osgood Semantic Differential Scales, measuring self-perceptions and perceptions of their preferred dating partner.

* Received in the Editorial Office, Provincetown, Massachusetts, on February 24, 1977. Copyright, 1978, by The Journal Press.

1 An expanded version of this Note, including a complete tabulation of the data and a critical review of Winch's complementarity hypothesis, may be obtained from the first author on request.

${ }_{2}$ Winch, R. F. Mate Selection: A Study in Complementary Needs. New York; Harper \& Row, 1958. 
Pearson product-moment correlations were computed between the $S$ s' self-perceptions and their perceptions of preferred dating and marriage partners. Positive and significant correlations indicated that they preferred partners similar to their own self-images, while negative and significant correlations showed a preference for complementary partners.

Out of 234 correlations, $210(89.7 \%)$ were positive and $24(10.3 \%)$ were negative. There were $181(77.3 \%)$ positive and significant correlations, and only $10(4.3 \%)$ negative and significant correlations. The rest of the negative correlations were not significant. All the negative and significant correlations were associated with only one item (masculine-feminine).

These results lend strong support to the idea that there is a tendency for both male and female students to look for a similar rather than a complementary dating and marriage partner, and that this tendency-which includes psychological and physical characteristics as well as social ones-is not a function of the marriage itself.

While this certainly holds good for the particular results obtained in the United States, Australia, and New Zealand, it should be noted that these three societies are fairly similar ones and that the present findings are limited to high school and university students in those countries. Accordingly, we hope that our study will be only the beginning of cross-cultural research in this area.

Department of Psychology

Victoria University of Wellington

Private Bag, Wellington, New Zealand

International House

500 Riverside Drive

New York, New York 10027 